\title{
Development of Competency Framework for Nigerian TVET Teachers in Tertiary TVET Institutions
}

\author{
Chee Sern Lai $^{1^{*}, \text { Mohammed Adamu Hamisu }^{2} \text {, Kahirol Mohd Salleh }}{ }^{1}$
}

\author{
${ }^{1}$ Universiti Tun Hussein Onn Malaysia, Parit Raja, Batu Pahat, 86400, MALAYSIA \\ ${ }^{2}$ Abubakar Tatari Ali Polytechnic, Bauchi, NIGERIA
}

DOI: https://doi.org/10.30880/jtet.2019.11.01.002

Received $31^{\text {st }}$ August 2019; Accepted $11^{\text {st }}$ November 2019; Available online $31^{\text {st }}$ March 2019

\begin{abstract}
Competency framework is a tool that determines the needed competencies for individuals in order to curtail the challenges that are existing currently and to uphold sustainable development. From the educational perspective, the competencies of TVET teachers are important as they might affect the teachers' implementation of tasks, career development and graduates' quality. Therefore, this research attempted to develop a competency framework for TVET teachers in Nigerian TVET tertiary institutions based on the Malaysian Human Resource Practitioners Development (MHRDP) Competency Model. The study adopted a survey design and 427 TVET teachers were identified as targeted sample. A set of questionnaire was developed based on the MHRDP Competency Model $(\alpha=0.61)$. A total of 218 questionnaires were distributed to five TVET tertiary institutions using stratified sampling technique and 205 questionnaires were successfully returned. Exploratory Factor Analysis was used to analyse the data. The findings revealed that 19 elements of competency were significantly relevant to Nigerian TVET teachers who work at tertiary institutions. The proposed competency framework is beneficial to be used as a guideline for the Nigerian TVET institutions and policy makers to plan the competency training and retraining courses for TVET teachers and staff development.
\end{abstract}

Keywords: TVET, competency framework, teacher, tertiary institution

\section{Introduction}

Competency is a vital element for assessing the quality of technical and vocational education and training (TVET) teachers. Competencies of TVET teachers are related to skills, knowledge, attitudes, values, and appreciations that are considered as critical elements for career development (Andersson \& Köpsén, 2015; Arifin \& Rasdi, 2017). TVET teachers need to be competent in content delivery, skill training, and managing classroom. Similarly, they should also be competent in handling teaching aids, assessing and evaluating students, possessing effective teaching methodology, recognising students learning style, meeting the needs of students in the classroom, and more importantly, being a role model to the students (Okoye \& Ofonmbuk, 2015; Oluwasola, 2014; Oni, 2007).

There are numerous challenges faced by TVET teachers not only in Nigeria, but also in other parts of the world especially in the developing countries. For example, TVET teachers do not have sufficient training related latest technology and pedagogy. This will definitely affect the competency of TVET teachers and, in turn, jeopardising their career development (Salleh, Khalid, Sulaiman, Mohamad, \& Sern, 2015). Therefore, pragmatic action should be taken to deal with this issue. Many countries, like United Kingdom, Malaysia, Australia, Indonesia, New Zealand and Ghana, have made some readjustments for the delivery of TVET by introducing the competency framework which has proven to be effective (Chua \& Jamil, 2012). Competency framework is a comprehensive structure that describes the key 
elements of competency with its specific set of behavioural constituents. The competency framework that contains competency elements can be applied to tertiary institution in order to minimise the existing challenges (Hamisu, Salleh, Sern, Adamu, \& Gambo, 2017). To date, there is no competency framework for TVET teachers within the context of Nigeria. Therefore, this research was conducted to propose a competency framework for TVET teachers which is expected to be applicable to TVET tertiary institutions. The development of the competency framework in this research was based on the Competency Framework of Malaysian Human Resource Practitioners Development (MHRDP) for Workplace Learning and Performance (WLP) developed by Salleh (2012).

\subsection{Malaysian Human Resource Development Practitioners (MHRDP) Competency Model for Workplace Learning and Performance (WLP)}

MHRDP competency model for WLP developed by Salleh (2012) was based on the American Society for Training and Development (ASTD) WLP which was developed by Rothwell, Sauders, and Soper (1999). The ASTD has been in existence for many years and it contains six components and 52 elements of competencies. Whereas the MHRDP competency model is made up of three components, namely Organisational Competency, Thinking Competency, and Application Competency. Within these three components, there are 25 elements in which Organisational Competency consists of 10 elements, Thinking Competency consists of 8 elements and Application Competency comprises 7 elements.

There are differences between the ASTD model and the MHRDP model due to the socio-cultural differences between the US and Malaysia (Salleh, 2012). In addition, the ASTD model was tested in the industrial settings (Peerapornvitoon, 1999; Yang, 1994; Yoo, 1999), whereas the MHRDP competency model has been used and tested in educational institutions and industries. Table 1 shows the previous studies using ASTD and MHRDP.

Table 1 - Competency model used by previous researchers

\begin{tabular}{lllll}
\hline Competency model & Researcher & Year & Location & Organisation \\
\hline ASTD & Chew & 2003 & Taiwan & Industries \\
ASTD & Peeraporn & 1999 & Thailand & Industries \\
ASTD & Salleh & 2012 & Malaysia & Industries \\
ASTD & Yang & 1994 & South Korea & Industries \\
ASTD & Yoo & 1999 & North Korea & Industries \\
MHRDP & Ahmad & 2015 & Malaysia & Community college \\
MHRDP & Ahmad & 2015 & Malaysia & Skills institute \\
MHRDP & Mohamad & 2016 & Malaysia & Public sector \\
\hline
\end{tabular}

Most of the studies that ultilised ASTD competency model for WLP only focused only on industries and corporate organisations. On the contrary, the MHRDP model has been used in different work environments such as educational institutions and governmental agencies (Ahmad, Salleh, Sulaiman, \& Latif, 2016; Ahmed, Khalifah, Sadiq, \& Faheem, 2015; Salleh, 2012). The MHRDP competency model for WLP was chosen for this research because this model has been proven to be reliable, and appears to be more suitable for this research since both Nigeria and Malaysia are developing countries. In addition, the use of the MHRD competency model as a benchmark in this study is also due to the fact that many institutions have adapted and adopted this competency model to develop competency framework (Berge, de Verneil, Berge, Davis, \& Smith, 2002).

For the purpose of this research, the MHRDP competency model was modified in order to guide the development of competency framework that would suit the Nigerian tertiary institution policies and vision as well as to serve as a tool for measuring current and future plans for the development of TVET teachers in Nigerian tertiary institutions.

\subsection{Conceptualization of TVET Teacher Competency Framework}

Fig. 1 presents the conceptual framework of the study which shows the relationship between the competency components and their elements, namely Organisational Competency, Thinking Competency and Application Competency. 


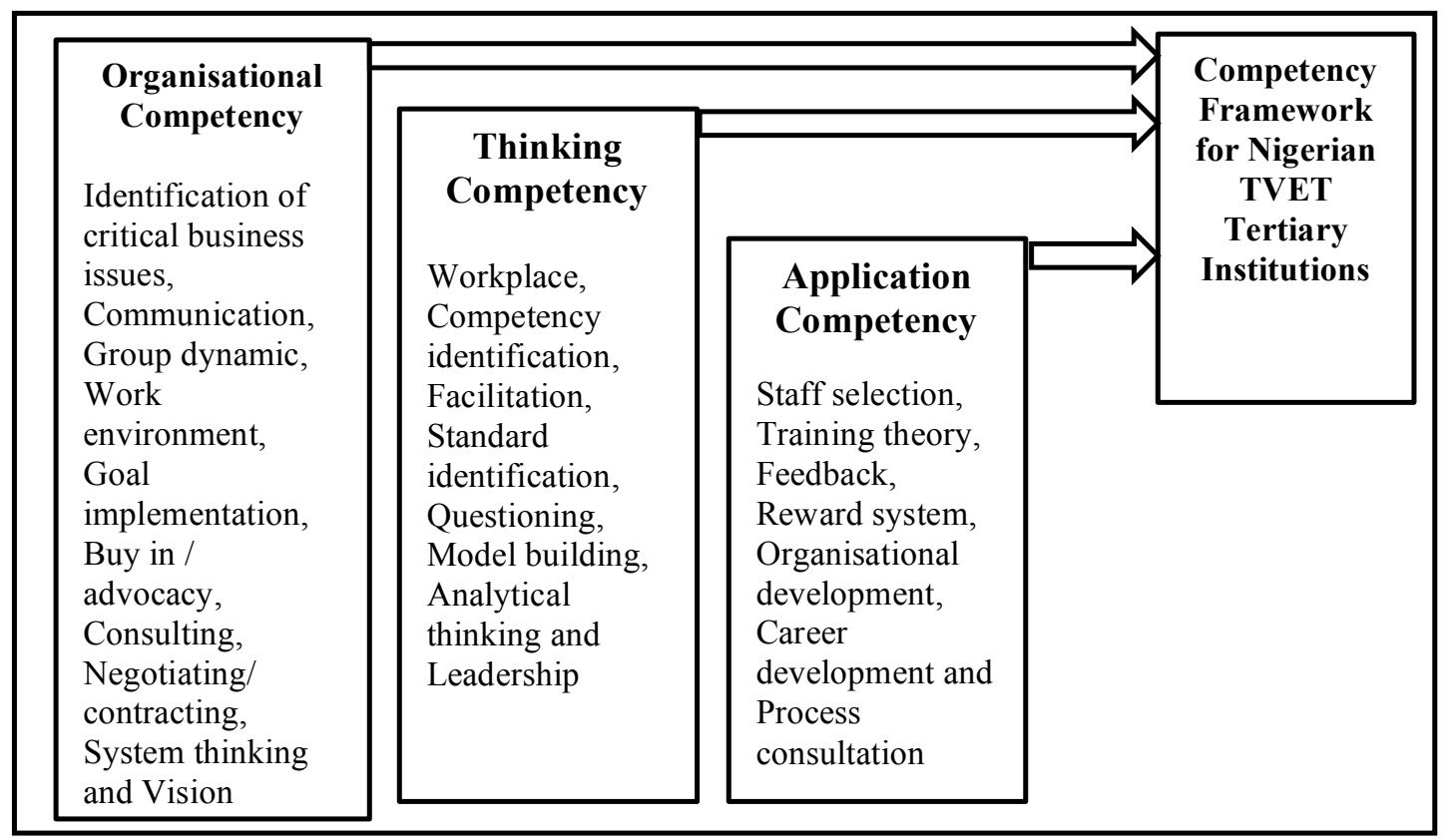

Fig. 1- Competency framework adapted from Salleh (2012).

Organisational Competency is related to the features of organisation that contribute to the quality in the arena of work (Garavan \& McGuire, 2001). According to Salleh (2012), the organisational competencies are the needed skills, knowledge and attitude which are required by employees of an organisation. Some of these competencies include: identification of critical entrepreneurial issues, communication, group dynamics, work environment analysis, goal implementation, buy-in/ advocacy, consulting, negotiating/contracting, systems thinking and visioning (Salleh, 2012). The significance of the organisational competency is to verify the skills levels of employees that need to be transferred to the workplace. Moreover, Garavan and McGuire (2001) posited that the organisational competency is important as it is used as a guideline to facilitate the process of assessing the suitability and expertise of a worker in completing the task assigned to them.

Thinking competency is with regard to knowledge and skills to analyse his/her own thinking about the information he/she receive which involve analysing, evaluating, and synthesising the information (Rycus \& Hughes, 2000). It is the combination of skills and knowledge that help employees to accomplish their duties effectively and efficiently in organisation by deciding what is right to do. Thinking competency is important to support long term plans in regards to the workers' skill and career development process and professionalism in an organisation (Heong, Sern, Kiong, Binti Mohamad, 2016). Thinking competency allows employees to initiate, create, develop, process and generate good ideas that can shape the direction of an organisation. In the MHRDP competency framework, the Thinking Competency is composed of workplace performance, learning strategies and intervention evaluation, competency identification, facilitation, standard identification, questioning, model building, analytical thinking and leadership (Salleh, 2012).

Application competency is concerning behaviours and attitudes of an individual that are applied in the workplace (Suhairom, Musta'amal, Amin, \& Johari, 2014). Application competency will help the employees to recognise and understand the needed behaviours, knowledge, morale, attitude, and values that are required to be applied in organisation. For example, applying TQM (Total Quality Management) to improve customer satisfaction can be regarded as Application Competency. According to Salleh (2012), the Application Competency includes staff selection theory and application, training theory and application, feedback, reward system theory and application, institutional development theory and application, career development theory and application and process consultation.

\section{Methodology}

The study adopted a survey design and was conducted in tertiary TVET institutions of Bauchi State. Bauchi was selected as a research location because it is the state in the North Eastern geopolitical zone of Nigeria with the highest number of tertiary TVET institutions.

\subsection{Sample}

The population of the study comprised 427 TVET teachers from five tertiary institutions (one University, one Polytechnic and three Colleges of Education). The proportionate stratified sampling technique was used for respondent selection. A total of 218 TVET teachers were selected to participate in the study. This sample was considered to be adequately 
representative to the entire population of 427 TVET teachers based on 95\% level of confidence and 5\% margin of error in accordance with the sample size determination table (Saunders, Lewis, \& Thornhill, 2016). Only 205 respondents had completed the questionnaire. Out of the total participating TVET teachers, 166 respondents were male and 39 were female TVET teachers.

\subsection{Instrument}

The instrument used for data collection was a structured questionnaire adapted from Salleh (2012) which was designed based on MHRDP competency model. The questionnaire was composed of 25 items and five-point scale ranging from 1 $=$ not important to $5=$ extremely important was used for all items. In specific, Organisational Competency contained ten items, Thinking Competency had eight items, and seven items was used to measure Application Competency. A total of 218 questionnaire was distributed to the respondents and 205 were returned which represents about $94 \%$ of response rate. The questionnaire yielded sufficient level of reliability, $\alpha=0.61$.

\subsection{Data Analysis}

In this research, Exploratory Factor Analysis (EFA) was used to analyse and measure the whole constructs in order to determine the suitable items of competency model to be applied for Nigerian tertiary TVET institutions.

\section{Results}

Prior to conducting the EFA, the appropriateness of data needs to be assessed (Adèr, Mellenbergh \& Hand, 2008). The first data screening procedure was concerning sampling adequacy in which Kaiser-Meyer-Olkin measure (KMO) was used. The Kaiser-Meyer-Olkin measure (KMO) of sampling adequacy value was checked where the result was 0.60 which is in line with the recommended minimum value of 0.5 (Yong \& Pearce, 2013). The Bartlett's test of Sphericity was also conducted to test the homogeneity of variances (Bartlett, 1964; Williams, Onsman \& Brown, 2010). The result showed that the Bartlett's test of Sphericity was significant, $X^{2}(171)=5104.33, p<0.001$. The 25 elements or items used from the aforementioned three components were subjected to principal component analysis which revealed the presence of three components (thinking, organisational and application competencies) with eigenvalues more than one and explained variances were $26.43 \%, 15.99 \%$, and $11.78 \%$ respectively. The final results indicated that six elements were removed due to poor factor loadings. In specific, two elements from each competency components were removed (Organisational Competency: Competency Identification, and Questioning; Thinking Competency: Critical Entrepreneurial Issues, and Group Dynamic, and Application Competency: feedback, and Institutional Development).

\subsection{Determination of competency framework elements}

The first construct was labelled as Thinking Competency in which six elements were found to load under it. The second construct (Organisational Competency) consisted of eight elements loaded under it. Whereas the third construct or Application Competency comprised five elements loaded onto it. All the elements used during the analysis were reduced to 19 elements. Those elements are considered more appropriate to the competency framework for Nigerian tertiary TVET institutions. Table 3 illustrates the remaining 19 elements.

In specific, there are six elements loaded onto Thinking Competency which includes workplace, facilitation, standard identification, model building, analytical thinking and leadership. These are the most appropriate elements of competency to develop the competency framework for Nigerian tertiary TVET institutions based on the respondents' perception. The elements' loadings range between 0.8 and 1.0 which can be regarded as a good factor loading (Pallant, 2011).

Apart from that, there are eight elements loaded into Organisational Competency, namely, communication, work environment, goal implementation, buy in / advocacy, consulting, negotiating/contracting, system thinking and vision. These elements are considered as relevant to the proposed competency framework for Nigerian TVET tertiary TVET institutions based on the respondents' opinion. The factor loadings for those elements range from 0.4 to 0.9. Nevertheless, there are three elements (negotiating, system thinking, and vision) with the factor loadings below 0.5. According to Matsunaga (2010), the loading of 0.4 is acceptable although larger than 0.5 is recommended. Finally, there are five elements loaded into the Application Competency, namely, staff selection theory and application, training theory and application, career development theory and application, reward system theory and application and process consultation. The factor loadings for those elements ranges between 0.4 and 0.9 which are also acceptable. These elements are considered as appropriate to be used for developing the framework for Nigerian tertiary TVET institutions. 
Table 3 - Determination of competency framework elements

\begin{tabular}{|c|c|c|c|}
\hline Items & $\begin{array}{c}\text { Thinking } \\
\text { Competency }\end{array}$ & $\begin{array}{c}\text { Organisational } \\
\text { Competency }\end{array}$ & $\begin{array}{l}\text { Application } \\
\text { Competency }\end{array}$ \\
\hline Workplace & .961 & & \\
\hline Facilitation & .960 & & \\
\hline Standard identification & .957 & & \\
\hline Model building & .890 & & \\
\hline Analytical thinking & .862 & & \\
\hline Leadership & .816 & & \\
\hline Communication & & .843 & \\
\hline Work environment & & .833 & \\
\hline Goal implementation & & .591 & \\
\hline Buy in / Advocacy & & .585 & \\
\hline Consulting & & .515 & \\
\hline Negotiating /Contracting & & .487 & \\
\hline System thinking & & .450 & \\
\hline Vision & & .434 & \\
\hline Staff selection theory and application & & & .833 \\
\hline Training theory and application & & & .825 \\
\hline Career development theory and Application & & & .544 \\
\hline Reward system theory and application & & & .537 \\
\hline Process consultation & & & .488 \\
\hline
\end{tabular}

\section{Discussion}

The proposed competency framework for Nigerian tertiary TVET institutions was developed from 25 competencies based on three components: Organisational, Thinking and Application Competencies. The present findings revealed that only 19 elements of competency are relevant to Nigerian tertiary TVET institutions. It is imperative to equip the Nigerian TVET teachers with these competencies in order to allow the TVET teachers to compete with their counterparts from other parts of the world. The competencies possessed by TVET teachers will determine the efficiency of TVET institutions and the quality of graduates (McLagan, 2002).

Specifically, the 19 elements are composed of (i) Thinking Competency (workplace, facilitation, standard identification, model building, analytical thinking and leadership) (ii) Organisational Competency (communication, vision, work environment, goal implementation, buy in/ advocacy consulting, negotiation and system thinking) and (iii) Application Competency (staff selection, training theory, career development, reward system and process consultation). These competency elements will be used to come up with the competency framework for Nigerian TVET teachers. The 19 elements were perceived by TVET teachers as appropriate to be part of the competency framework because those elements are very relevant to their jobs and duties in TVET institution. For example, communication was perceived as relevant to Organisational Competency because the participating TVET teachers were faced with problem associated with communication (e.g., communication with top management personnel) (Ezeuko \& Mbagwu, 2009). From the TVET teachers' point of view, it is vital to possess good communication skill either with their superintendents, colleagues, or students.

Apart from that, there were six elements removed from the existing model. The removed elements (Identification, and Questioning, Critical Entrepreneurial Issues, and Group Dynamic, feedback, and Institutional Development) are also critical for TVET institutions in general and TVET teachers in specific. Those elements, however, were not in line with the Organisational, Thinking, and Application Competencies. In other words, those elements do not belong to any competency components measured in this research. Figure 2 shows the competency framework that could contribute to the development of TVET teachers' competency in the Nigerian tertiary institutions. 


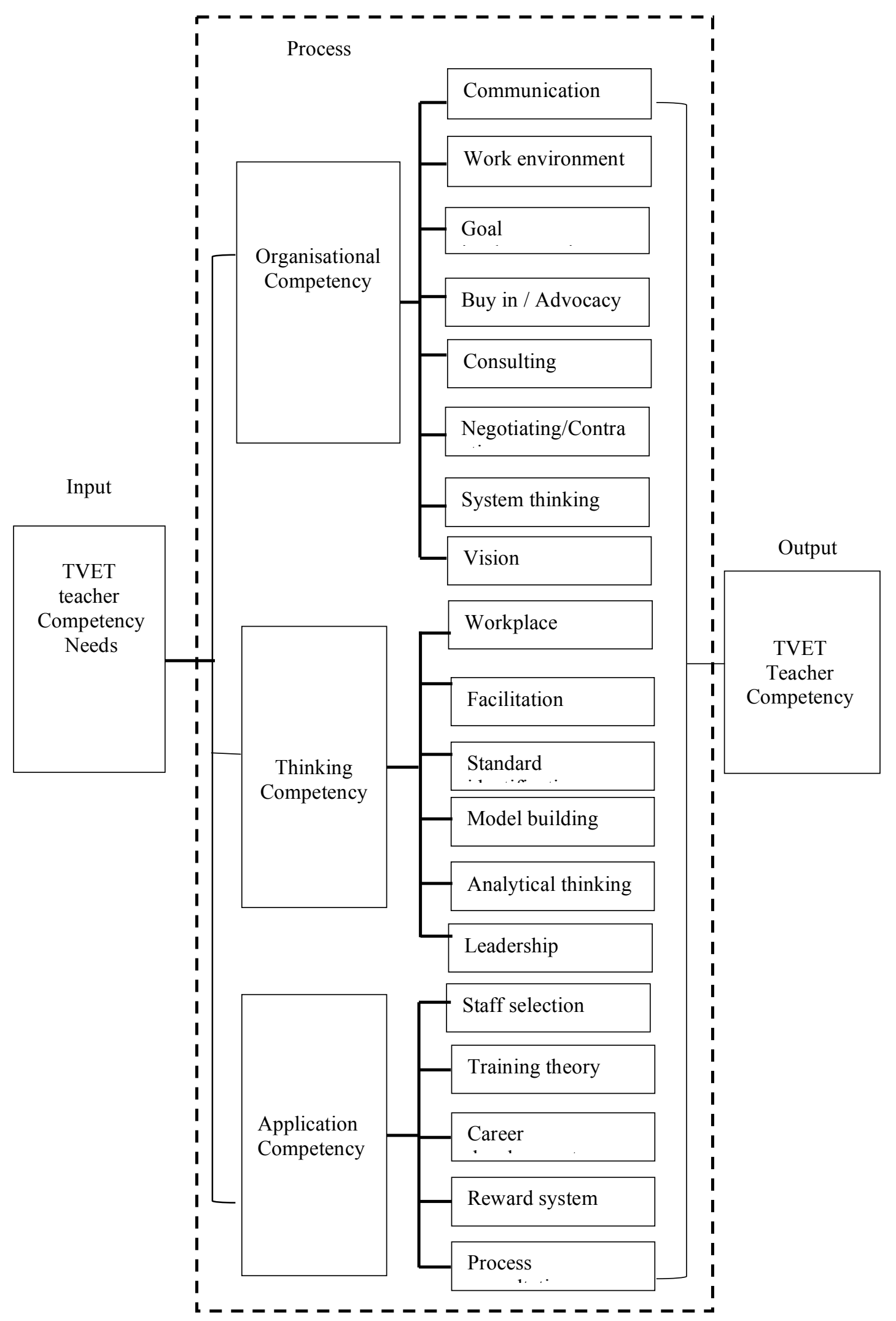

Fig. 2 - Competency framework for Nigerian tertiary TVET institution. 


\section{Conclusion}

The competency framework for Nigerian TVET tertiary institutions was developed based on the 19 elements of competency derived from three major components, namely eight elements from Organisational Competency, six elements from Thinking Competency, and five elements from Application Competency.

This research is important because the proposed competency framework can be applied to various fields of knowledge within the sphere of TVET. In addition, the competency framework also serves as a guideline for the top management of TVET institution and policy makers to plan the competency training and retraining courses for TVET teachers and staff development. Nonetheless, the present research only involved TVET teachers, therefore, future research is suggested to be undertaken to develop a competency framework for non-TVET institutions.

\section{Acknowledgement}

This project was partially supported by UTHM under Grant PPG (V026).

\section{References}

Adèr, H.J., Gideon J. Mellenbergh, G.J. and Hand, D.J. (2008). Advising on Research Methods: A Consultant's Companion. Huizen, the Netherlands: Johannes van Kessel Publishing

Ahmad, M. Salleh, K. M., Sulaiman, N. L., \& Latif, A. A. (2016). The Development of Human Resource Competency Model in Public Sector Organizations in Malaysia, International Journal of Applied Business and Economic Research, $1(2), 78-97$.

Ahmed, I., Khalifah, Z., Sadiq, M., \& Faheem, M. A. (2015). Graduates' Expectation Gap: The Role of Employers and Higher Learning Institutes. Journal of Applied Research in Higher Education, 7(2), 372-384.

Andersson, P., \& Köpsén, S. (2015). Continuing Professional Development of Vocational Teachers: Participation in A Swedish National Initiative. Empirical Research in Vocational Education and Training, 7(1), 1-20.

Arifin, M. A., \& Rasdi, R. M. (2017). The Competent Vocational College Teacher: A Proposed Model for Effective Job Performance. International Journal of Academic Research in Business and Social Sciences, 7(2), 829-837.

Bartlett, M. S. (1964). The spectral Analysis of Two-Dimensional Point Processes. Biometrika, 51(3), 299-311

Berge, Z., de Verneil, M., Berge, N., Davis, L., \& Smith, D. (2002). The Increasing Scope of Training and Development Competency. Benchmarking: An International Journal, 9(1), 43-61.

Chua, J. H., \& Jamil, H. (2012). Factors Influencing the Technological Pedagogical Content Knowledge (Tpack) Among TVET Instructors in Malaysian TVET Institution. Procedia-Social and Behavioral Sciences, 69, 1539-1547.

Dubois, D., \& Rothwell, W. (2004). Competency-Based Human Resource Management: Discover A New System for Unleashing the Productive Power of Exemplary Performers. Nicholas: Brealey Publishing.

Ezeuko, R.O. and Mbagwu, D.U. (2009). Ineffective Communication in Nigeria: A Problem Associated With Low Level of Literacy, Unizik Journal of Arts and Humanities, 10(2), Retrieved from https://www.ajol.info/index.php/ujah/article/view/67012

Garavan, T. N., \& McGuire, D. (2001). Competencies and Workplace Learning: Some Reflections on the Rhetoric and the Reality. Journal of Workplace Learning, 13(4), 144-164.

Hamisu, M. A., Salleh, K. M., Sern, L. C., Adamu, B. Y., \& Gambo, K. (2017). Proposed Competency Model for Technical and Vocational Education and Training (TVET) Lecturers Teaching in Technical Colleges, Bauchi State in Perspective. Path of Science, 3(9), 5001-5009

Heong, Y.M., Sern, L.C., Kiong, T.T., Binti Mohamad, M.M. (2016). The Role of Higher Order Thinking Skills in Green Skill Development, MATEC Web of Conferences, 70, DOI: 10.1051/matecconf/20167005001

Ismail, S., \& Mohammed, D. S. (2015). Employability Skills in TVET Curriculum in Nigeria Federal Universities of Technology. Procedia-Social and Behavioral Sciences, 204, 73-80.

Matsunaga, M. (2010). How to Factor-Analyze Your Data Right: Do's and Don'ts, and How-To’s, International Journal of. Psychol Res, 3 (1), 97-110.

McLagan, P. A. (2002). Change Leadership Today. Training \& Development, 56(11), 26-26.

Okoye, K. R., \& Ofonmbuk, I. M. (2015). Enhancing Technical and Vocational Education and Training in Nigeria for Sustainable Development: Competency Based Training Approach. Journal of Education and Practice, 6(29), 66-69. 
Oluwasola, A. J. (2014) Professional Competence of Technical Teachers: A Factor Analysis of the Training Needs of Technical College Teachers in Ekiti State. Journal of European Education, 3(5) 281-293.

Oni, C. S. (2007). Globalization and Its Implications for Vocational Education in Nigeria. Essays in Education, 21(1), 30-34.

Pallant, J. (2011). SPSS Survival Manual (4th ed), New York, NY: Open University Press.

Peerapornvitoon. M. (1999). A Survey of Workplace Learning and Performance: Competencies and Roles for Practitioners in Thailand. Pennsylvania State University: Unpublished doctoral dissertation.

Rothwell, W. J., Sanders, E. S., \& Soper, J. G. (1999). ASTD models for workplace learning and performance: Roles, competencies, and outputs. Washington DC: American Society for Training and Development.

Rychen, D. S. E., \& Salganik, L. H. E. (2001). Defining and Selecting Key Competencies. Ashland, Ohio USA: Hogrefe \& Huber Publishers.

Rycus, J., \& Hughes, R. (2000). What Is Competency-Based In-Service Training? Ohio, Columbus: Institute for Human Services.

Salleh, K. M. (2012). Human Resource Development Practitioners Perspectives on Competencies: An Application 0f American Society for Training and Development (ASTD) Workplace Learning And Performance (WLP) Competency Model In Malaysia. Colorado State University: PhD. Thesis.

Salleh, K. M., Khalid, N. H., Sulaiman, N. L., Mohamad, M. M., \& Sern, L. C. (2015). Competency of Adult Learners in Learning: Application of the Iceberg Competency Model. Procedia-Social and Behavioral Sciences, 204, $326-334$.

Saunders, M., Lewis, P., \& Thornhill, A. (2016). Research Methods for Business Student. (7 ${ }^{\text {th }}$ ed). England: Pearson Education Limited

Suhairom, N., Musta'amal, A. H., Amin, N. F. M., \& Johari, N. K. A. (2014). The Development of Competency Model and Instrument for Competency Measurement: The Research Methods. Procedia-Social and Behavioral Sciences, 152, 1300-1308.

Williams, B., Onsman, A., \& Brown, T. (2010). Exploratory Factor Analysis: A Five-Step Guide for Novices. Australasian Journal of Paramedicine, 8(3). Retrieved from http://ro.ecu.edu.au/jephc/vol8/iss3/1

Yang, J. C. (1994). Perceived Competencies Needed by Human Resource Development Managers in Korea. Korea: University of Minnesota: PhD. Thesis.

Yong, A. G., \& Pearce, S. (2013). A beginner's guide to factor analysis: Focusing on exploratory factor analysis. Tutorials in quantitative methods for psychology, 9(2), 79-94. 